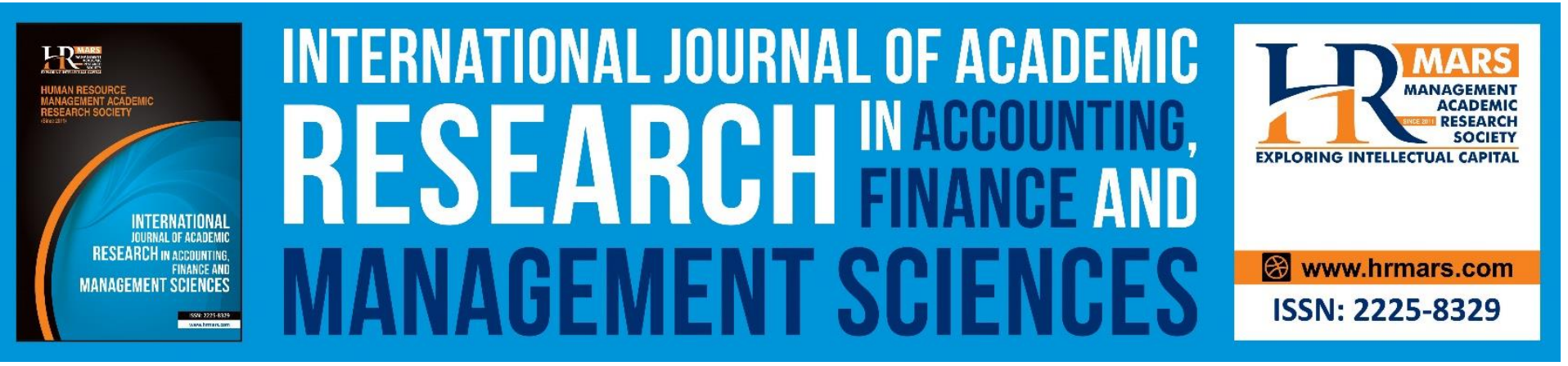

\title{
Capital Structure of Surviving Family Firm in Malaysia
}

\section{Haslindar Ibrahim, Teik-Cheng Lau, Afizar Amir}

To Link this Article: http://dx.doi.org/10.6007/IJARAFMS/v11-i2/8347

DOI:10.6007/IJARAFMS /v11-i2/8347

Received: 10 March 2021, Revised: 11 April 2021, Accepted: 29 Arpril 2021

Published Online: 19 May 2021

In-Text Citation: (Ibrahim et al., 2021)

To Cite this Article: Ibrahim, H., Lau, T.-C., \& Amir, A. (2021). Capital Structure of Surviving Family Firm in Malaysia. International Journal of Academic Research in Accounting Finance and Management Sciences, 11(2), 62-89.

Copyright: (c) 2021 The Author(s)

Published by Human Resource Management Academic Research Society (www.hrmars.com)

This article is published under the Creative Commons Attribution (CC BY 4.0) license. Anyone may reproduce, distribute, translate and create derivative works of this article (for both commercial and non-commercial purposes), subject to full attribution to the original publication and authors. The full terms of this license may be seen

at: http://creativecommons.org/licences/by/4.0/legalcode

\section{Vol. 11, No. 2, 2021, Pg. 62 - 89}

Full Terms \& Conditions of access and use can be found at http://hrmars.com/index.php/pages/detail/publication-ethics 


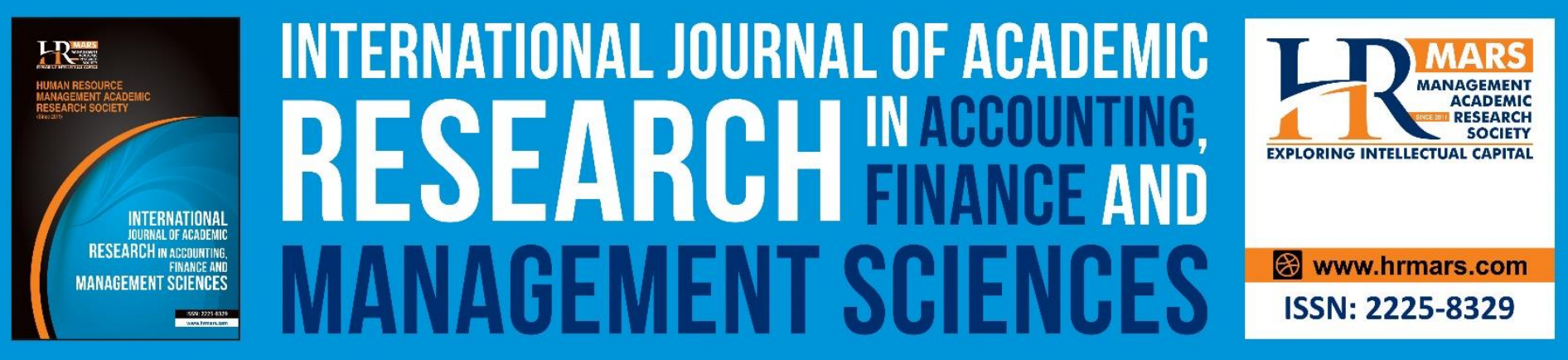

\title{
Capital Structure of Surviving Family Firm in Malaysia
}

\author{
Haslindar Ibrahim, Teik-Cheng Lau \\ School of Management, Universiti Sains Malaysia, Malaysia \\ Email: haslindar@usm.my, andylau_tc@hotmail.com \\ Afizar Amir \\ School of Distance Education, Universiti Sains Malaysia, Malaysia \\ Email: afizar0074@gmail.com
}

\begin{abstract}
This paper examines the relationship between the determinants and capital structure of surviving family firm in Malaysia with 151 listed companies from 2000 to 2015. Tangibility, growth opportunities, profitability and liquidity as determinants and short term debt, long term debt and debt ratio are the dependent variables. By using panel data, all determinants are significant to debt ratio for surviving family. In a nutshell, surviving family companies prefer to use internal sources as main priority for financial leverage decisions to sustain its business. The results reveal that surviving companies have sufficient liquid assets, can utilize these funds to finance business activities and have lower leverage.
\end{abstract}

Keywords: Capital Structure, Surviving Family Firms, Tangibility, Liquidity, Debt Ratio, Pecking Order Theory.

\section{Introduction}

The firm's preference of an ideal capital structure decision remains one of the large unresolved issues in the financial economics literature. The capital structure has commonly determined by the original theory which developed by Modigliani and Miller (1958). As reported by Brealey, Myers and Allen (2006), capital structure is defined as the company's amalgamation of equity financing and debts, with the aim of financing its company's investment (Myers, 2001; Pratomo and Ismail, 2006). Nevertheless, the capital structure still considered as the relative amalgamation of the debt and the equity securities in long term of the firm's financial framework (Megginson, 1997).

In fact, the capital structure, working capital adequacy and asset performance are well known investment quality measurements, which can be used to evaluate the strength of a company's balance sheet. Commonly, most of the investors can analyse the balance sheet as one's of the main considerations before making any investment decision to invest in listed company's shares. Generally, the indicator of the ratio for debt and equity to support company's assets are considered 
INTERNATIONAL JOURNAL OF ACADEMIC RESEARCH IN ACCOUNTING, FINANCE AND MANAGEMENT SCIENCES

Vol. 11, No. 2, 2021, E-ISSN: 2225-8329 @ 2021 HRMARS

a very significant and powerful indicator key for accessing the balance sheet strength. As a result, most of the investors shall prefer a capital structure appertains, of low debt and high equity leverage, whereby a positive signal for a very good investment quality especially in return with a positive stock market portfolio.

Nowadays, family business ownership whether listed or not listed companies have becoming a very significant element in the corporate economy, played a vital role in a country contribution and become popular topic in the research study. It is mainly due to the proven track recorded performance of the established family companies throughout a long period of time. Still, most of the successful and outstanding companies have a family ownership background which being noticed and acknowledged by scholars and practitioners. In the real world, the excellent performance, outstanding, surviving and sustainable family background companies can be discovered, for example companies like IKEA, Mitsubishi, Wal-Mart, Genting, IOI, YTL and so on, owned, founded and operated by family member background, which had higher competitive capabilities in the business world.

Many academic articles demonstrated that Asian family background companies had a greater performance in the following countries, particularly Hong Kong, Singapore, China, Australia and Taiwan (La Porta, Lopez-De-Silanes and Shleifer, 1999; Chen, 2000; and Filatotchev, Lien and Piesse, 2005). As for Malaysia, there are several family business companies with a remarkable performance, well-known, historical and yet sustainable family background companies are Kuok Hock Nien (Kuok Brothers's group), Lim Goh Thay (Genting's group), Quek Leng Chan (Hong Leong group), Yeoh Tiong Lay (YTL), Lee Shin Ching (IOI group), had contribute to the development of the Malaysian economy. Therefore, family-based companies are ever since dominating the corporate world with established, outstanding and sustainable performance in each country respectively (Ibrahim and Samad, 2011).

According to Gorriz and Fumas (2005), they explain about the surviving listed firms by referring to those companies which can maintain and remain listed in the stock market for at least 15 years continuously. In their study, they find that the performance of the surviving family listed firms in Spanish have higher productive efficiency than surviving non-family listed firms. Thus, this study adopted the year of surviving at least 15 years remain listed on the Bursa Malaysia. Therefore, the main objective of this study is to examine the relationship between tangibility, growth opportunities, profitability and liquidity against financial leverage to explore the financing characteristics or behavior of family firms.

The remainder of this paper is organized as follows. Section 2 discusses the relevant literature on leverage, determinants and hypothesis development. Section 3 describes the methodology and data. Section 4 presents the main results and discussions of the empirical analysis. Section 5 concludes and provides some implications.

\section{Literature Review}

The study of capital structure strives to elucidate the combination of securities and capital sources implemented by companies to finance investment. Numerous academic and practical researches 
INTERNATIONAL JOURNAL OF ACADEMIC RESEARCH IN ACCOUNTING, FINANCE AND

MANAGEMENT SCIENCES

Vol. 11, No. 2, 2021, E-ISSN: 2225-8329 @ 2021 HRMARS

have contributed a variety of forecasts and justification on corporation's leverage behavior given that the ground work was established by Modigliani and Miller (1963).

There was no commonly established theory of capital structure prior to Modigliani and Miller (1958). They acknowledged that the market value of a company is determined by the gaining power and its fundamental assets risk, value as self-determining of the method to finance its investments or allocate dividends. MM established the idea that the worth of an organization is depending on the organization's profitability. Therefore, the firms do not have an optimal capital structure as the ideal capital structure is changing in accordance with its industry, business nature and bankruptcy costs.

The trade-off theory (TOT) is one of the methods to determine that corporation's capital structure result involves a trade-off situation between the tax benefits of debt financing and the costs of financial distress. The cost of financial distress is based on the financial distress and cost of bankruptcy. In reality, this proposition aims that there is no reasonable sum of debt for any individual corporation. As a result, the best possible debt ratio (debt capacity) differs to each company. According to Titman and Wessels (1988), corporations that have safe tangible assets and various taxable incomes have high debt ratio.

The pecking order theory (POT), originated from Donaldson's research (1961) and main idea of POT is that managers introduce new finance in a meticulous order. POT capital structure assumes that firms prefer to increase company finance with internal funds, debt, preferred equity and common equity, in that particular order. Myers (2001) debats that so far, there is no complete theory of the debt-equity preference so there were various empirical researches viewed how theories affect company's funding and the discussion of empirical studies of capital structure as the guideline of suggested determinants. The POT as proposed by Myers and Majluf (1984), is explaining the effects of the information asymmetries between insiders and outsiders of company. According to theory, companies follow a preferential order of financing sources, and that before seeking debts, they would use internal funds. Thus, the more profitable companies would tend to have fewer debts and conversely low profitable companies use debt financing due to insufficient resources generated internally.

Following the lead of many prior empirical studies (Myers, 1984; Friend and Hasbrouk, 1988; Titman and Wessels, 1988; Rajan and Zingales, 1995; Wiwattanakantang and Yupana, 1999), which investigates the determinants of capital structure based on firm-specific factors, this study is focusing on surviving listed companies characteristics or behavior especially family firm that influence their capital structure decision or financial leverage.

\section{Family Firms' Characteristics and Financing Behaviours}

In recent years, although the academic research studies on family firms are increasingly popular, but it is limited because it short of latest information on this significant corporation structure. Past literature review about family companies normally only emphasize on performance related subjects (Villalonga and Amit, 2006; Miller et al., 2007; Silva and Majluf, 2008;). On the other hand, it has been discussed that family companies are more financial restrained than non-family companies because 
INTERNATIONAL JOURNAL OF ACADEMIC RESEARCH IN ACCOUNTING, FINANCE AND MANAGEMENT SCIENCES

Vol. 11, No. 2, 2021, E-ISSN: 2225-8329 ๑ 2021 HRMARS

they have advantages to maintain the controlling status of the family and might be refused to issue equity to investors as outsider (Berzins et al., 2013).

Furthermore, followed by Anderson and Reeb (2003), they also examine whether family companies have better concentrated ownership structure or not possesses control over the power, and this trait makes it extra complex to obtain minority investment from outsiders. Besides, they also test whether family companies consist of minority investors later than non-family firms. In addition, family companies with a CEO as a family member have a tendency of better protection interests of the family member. Still, family companies are also asserted as conservative and have a long term perspective in term of their business management practise (Bertrand and Schoar, 2006). In term of long term practise, it has been discussed that family firms are apprehensive with survival compared non-family firms (Miller et al., 2007).

According to Wahlqvist and Narula (2014), based on their research study, they stated that family firms are originally started financing with more debt than non-family firms. Besides, their early ownership structure is more determined than non-family companies' establishment. Still, their verdict suggests that family companies include minority investors afterward than non-family companies. If the CEO is a family member, then the companies most likely to include minority investors later than if the CEO is outside the family. These research findings are reliable with family firms' incentives to maintain control over the corporate management. On the other hand, family firms have the tendency to start up business with more long term debt financing than non-family firms. And their long term concentration is also considered in the outcome indicate that family firms survive longer compared to non-family firms over a period of time. Besides, capital structure shall affect family firm survival in term of the leverage is related with earlier death.

Moreover, Wahlqvist and Narula (2014) find that Norwegian family companies be likely to be financed with additional institutional debt than non-family companies. In addition, they too point out the momentary rule in 2005 caused by the tax reform in 2006, affect the capital structure of companies founded in that year. Furthermore, their research study also mentions about Norwegian family firms averagely are able to survive longer than non-family firms, but close down earlier if they are profoundly financed with debt leverage. Moreover, Croci, Doukas and Gonenc (2011) assert given that family companies are less transparent to external investors, the cost of equity relative to debt is higher for family companies than for non-family companies.

On the other hand, family background corporation will have to protect their ownership control by maintained its debt ratio level as low as possible. As for the family firms, the long term survival is important issues to continue to sustain their business. It has also been reported that family firm's short term debt ratio is lower than non-family firms as precaution survival strategy. Furthermore, family businesses companies tend to be conventional in financing decisions because the corporate culture decision had become a habit for the managers. The family firm's characteristic leads them to choose traditional bank offers in detriment of other options of capital, namely investment and venture capital, funding from the financial company, initial public offerings, and access to state or local funds. In addition, larger established family firms which may have outside board of directors or a non-family member shall be affecting directly in the role of financial decision making by applying 
INTERNATIONAL JOURNAL OF ACADEMIC RESEARCH IN ACCOUNTING, FINANCE AND MANAGEMENT SCIENCES

Vol. 11, No. 2, 2021, E-ISSN: 2225-8329 @ 2021 HRMARS

sophisticated financial management techniques. Moreover, family firms have a better current ratio than non-family firms indicating that family firms can carry out their financial obligation efficiently (Colot and Croquet, 2009).

Medeiros (2015) examines a sample of 194 family and non-family firms, from the year 2005 to 2013 where the business based in either European or North American countries. It discovers that family firms present lower leverage ratios than non-family firms and non-family firms rely more on long term debt than family firms. Furthermore, the study also claims that family firms tend to finance internally rather than external, either investing the cash-flows generated by the operations or the owner private funds. Then, the second choice only goes for debt and then followed by external equity. Sustainable family firms prefer debt over equity as the reason of they do not need to dilute or face diminishing role of firm's control ownership. Such behaviors of the family firm are consistent with the POT (Myers, 1984) whereby firms tend to have the following financing preferences: internal to external financing and debt to equity, in case external financing is used. However, non-family firms will not limit their financing from internally generated funds but will practice a market-oriented approach to funding, consequently acting toward growth oriented as compared to family firm's businesses (Medeiros, 2015).

Surprisingly, despite the importance of family businesses, the theories concerning capital structure have generally overlooked the influence of the quality of the contractual structure of family businesses that combines economic relations and family. Particularly, family firms could cause the practice of different financial sources and influence the financing decision of family businesses (Gallo, Tapies and Cappuyns, 2004; Croci et al., 2011). Family businesses are unique and follow the financial strategies different from other companies (Chua, Chrisman and Sharma, 1999; Zahra and Sharma, 2004). Habbershon and Williams (1999) posit that the distinctiveness of family businesses results from the associating of family and business life.

Basically, a family firm demonstrates a family's influence over the financial strategic direction of a firm, with the aim of the family to keep control, a specific family firm behaviour and uniqueness, inseparable, synergistic resources and competencies arising from family involvement and interactions (Miller and Le-Breton-Miller, 2006). Family firms' vision and objective for transgenerational sustainability lead the firms to the institutionalization by combining of family and business systems. In reality, when compared to publicly held companies, family firms have a long term perspective (Miller and Le-Breton-Miller, 2006).

Family firms sometimes pursue other than merely financial objectives such as the satisfaction of needs for belonging, affect and intimacy; the perpetuation of family values through the business; the conservation of the family dynasty; the conservation of the family firms social capital; the fulfilment of family obligations based on blood ties rather than on strict criteria of competence; and the opportunity to be altruistic toward family members (Gomez-Mejia, Haynes, Nunez-Nickel, Jacobson and Moyano-Fuentes, 2007; Zellweger and Astrachan, 2008). Family firms often reach a match of family proprietorship with brand identity (Craig, Dibrell and Davis, 2008). 
INTERNATIONAL JOURNAL OF ACADEMIC RESEARCH IN ACCOUNTING, FINANCE AND MANAGEMENT SCIENCES

Vol. 11, No. 2, 2021, E-ISSN: 2225-8329 @ 2021 HRMARS

The characteristic of financial behavior practiced by non-family firms could not be followed by family businesses (Lopez and Sanchez, 2007), due to the desire to sustain the control of the firms through generations, had restricted its financial resources and the capacity to acquire resources in general. Family managers usually choose their financial decisions on how these decisions may influence the family control of the firms rather than wide-ranging assessment of the financial issues (Croci et al., 2011).

Furthermore, there are still full of loopholes of the existing literature on the differences of family firm's use of debt and the issues that might influence capital structure on family and non-family firms (Ampenberger, Schmid, Achleitner and Kaserer, 2013). Most previous researchers have acknowledged that firms operate differently depending on the firm size, age, asymmetric information, growth opportunities, debt cost, liquidity and etc, that direct them to display different financial behaviour (Scherr and Hulburt, 2001; Ramalho and Da Silva, 2009). Several journals have also found evidence of changes in the financial structure of family firms during the firm's life cycle (Blanco-Mazagatos, De Quevedo-Puente, and Castrillo, 2007; Molly, Laveren and Deloof, 2010; La Rocca et al., 2011).

Family firms have captured more attention in the economics and finance literature since the latest research showing that the majority of firms around the world are controlled by their founders or their founders' descendants (La Porta et al.,1999; Morck, Stangeland, and Yeung, 2000; Faccio and Lang, 2002). Even in the United States, where firm ownership is widely dispersed (Berle and Means, 1932), founding families own and control at least one-third of large, publicly held firms (Anderson and Reeb, 2003). One of the majority controversial issues surrounding family firms connected to the chief executive officer (CEO) succession decisions. CEO adaptions are expected to play a crucial part in determining a firm's prospects, and possibly influenced by the preferences of controlling families, that is why it is hard to hired or choose a family member or unrelated CEO (Anderson and Reeb, 2003).

\section{Hypothesis Development}

This study will examine the relationship between asset tangibility, growth opportunities, profitability, and liquidity against short term debt, long term debt, and debt ratio of surviving family and nonfamily listed companies in Malaysia.

\section{Asset Tangibility and Leverage}

Asset tangibility is the major factor in determining the firm's debt level and the empirical studies proved that the asset tangibility is positively related to debt ratio (Long and Maltiz, 1985; Titman and Wessels, 1988; Friend and Lang, 1988; Williamson, 1988; Harris and Raviv, 1990; Rajan and Zingales, 1995; Wald, 1999). Moreover, Cekrezi (2013) empirical study proved that tangibility is significantly negative relation to short term debt and tangibility is significantly positive relation for long term debt and total debt. Such relationship indicates that firms do not finance their fixed assets with short term debt but however finance by using long term debt. This result consistents with Cole (2013) where he examines small and privately held corporation's capital structure decisions in the United States indicating that the leverage is significantly positively related to asset tangibility. Furthermore, Ahsan et al. (2016) in their studies find that asset tangibility has a positive relation with long term debt, but 
INTERNATIONAL JOURNAL OF ACADEMIC RESEARCH IN ACCOUNTING, FINANCE AND

MANAGEMENT SCIENCES

Vol. 11, No. 2, 2021, E-ISSN: 2225-8329 @ 2021 HRMARS

negative correlation with short term debt. This findings imply that Pakistani companies prefer retained earnings to finance their business operation.

In addition, a recent study by Hussain et al. (2015), investigate and examine the capital structure determinants of 45 listed companies in Malaysia's food producer industry from 2003 to 2012. The findings reveals that asset tangibility is found to be positively correlated to total debt ratio. Meanwhile, asset tangibility is positively related to total debt ratio consistent with Cekrezi (2013), Cole (2013), Vergas et al. (2015), Chadha and Sharma (2015) and Ahsan et al. (2016). Thus, the testable hypotheses for this study are:

H1a: Asset tangibility is negatively related to short term debt ratio of surviving family and surviving non-family companies.

$\mathrm{H} 1 \mathrm{~b}$ : Asset tangibility is positively related to long term debt ratio of surviving family and surviving non-family companies.

H1c: Asset tangibility is positively related to debt ratio of surviving family and surviving non-family companies.

\section{Growth Opportunities and Leverage}

Sinha (1992) claims a positive relation between growth and leverage because higher growth opportunities indicate that higher demand for funds as well. In line with pecking-order theory, company management prefers internal to external financing and debt to equity if it issues company securities (Myers 1984). So, it indicates that growing company's capital structure shall need a higher level of debt for its growth strategy as compared to a stagnant company. However, as for the agency cost theory, it is claimed that a negative correlation between growth opportunities and debt ratio. The theory implies that equity controlled firms are tending to invest sub-optimally to exploit wealth from the corporation's bondholders. The agency cost in growing corporations shall be higher as they might have more flexibility in future investment options (Baral, 2004).

Abor and Biekpe (2009) find that growth opportunities and long term debt are positive in relation whilst growth opportunities and short term debt in a negative correlation. Furthermore, Ahsan et al. (2016), they find growth has significantly correlated with long term debt and total debt, but negatively related to short term debt. In addition, Vergas et al. (2015) find that growth opportunities positively, in explaining the debt. Also, there were significantly varied for determinants in market valuation, tangibility and growth due to financial crisis year 2008. On the other hand, Ohman and Yazdanfar (2017) in their research study find significant positive relation among growth, short term debt and long term debt, meaning that small medium enterprises with a relatively high growth rate prefer to use more external financing. Furthermore, Hussain et al. (2015) find that the growth opportunities are to be positive but insignificant with total debt ratio. Therefore, the testable hypotheses for this study are:

H2a: Growth opportunities are negatively related to short term debt ratio of surviving family and surviving non-family companies.

$\mathrm{H} 2 \mathrm{~b}$ : Growth opportunities are positively related to long term debt ratio of surviving family and surviving non-family companies. 
INTERNATIONAL JOURNAL OF ACADEMIC RESEARCH IN ACCOUNTING, FINANCE AND

MANAGEMENT SCIENCES

Vol. 11, No. 2, 2021, E-ISSN: 2225-8329 @ 2021 HRMARS

H2c: Growth opportunities are positively related to debt ratio of surviving family and surviving nonfamily companies.

\section{Profitability and Leverage}

According to Rajan and Zingales (1995), they claim that theoretical predictions confliction between profitability on leverage. Based on POT, organizations tend to finance started from retained earnings, followed with debt and then until issuing new shares equity. As such, it happens to be a negative correlation between profitability and debt ratio (Myers and Majluf, 1984). Whilst Jensen (1986) forecast a positive relation if firm controls its market efficiently. Moreover, Rajan and Zingales (1995) suggest creditors could be more willingly approved to lend money to the profitable companies. Cekrezi (2013) empirical finding results show a significant negative connection between profitability and all financial leverage (short term, long term, total debt), consistent with Frank and Goyal (2009); Alipour et al. (2015); Vergas et al. (2015); Chadha and Sharma (2015). In sum, it concludes that more profitable corporations shall use its internal resources especially money from retained earnings to finance corporate business operations as a priority, whereby resulting firms shall borrow less as compare to less profitable firms, indicated support the pecking order theory.

Furthermore, Ahsan et al. (2016) finding also proved that profitability is negatively correlated to long term debt. In addition, Ohman and Yazdanfar (2017), finding results in deeper present that profitability is negatively and significantly linking to the short term debt and long term debt, meaning that more profitable Swedish SMEs are less applying external financing. On the other hand, Hussain et al. (2015) find that firm size, profitability and liquidity are significant negative related to total debt ratio in their research done in Malaysia. The testable hypotheses for this study are:

H3a: Profitability is negatively related to short term debt ratio of surviving family and surviving nonfamily companies.

$\mathrm{H} 3 \mathrm{~b}$ : Profitability is negatively related to long term debt ratio of surviving family and surviving nonfamily companies.

H3c: Profitability is negatively related to debt ratio of surviving family and surviving non-family companies.

\section{Liquidity and Leverage}

Pecking order theory recommends that corporations commonly prefer to finance by using internal funds first. So, those with sufficient liquid assets can utilize such funds to finance business operations and expect to have lower debts. Ahsan et al. (2016), state that negative correlation among liquidity to short term debt and total debt whereas this connection becomes positive related to long term debt. Nevertheless, Al-Ajmi et al. (2009) finding's results show that liquidity was significantly negative to short term debt, long term debt and debt ratio, which it matched to POT and TOT method. On the other hand, Deesomsak et al. (2004) organize a study to analyze the corporation's capital structure determinants which based on Asia Pacific area. Malaysia, Australia, Thailand and Singapore were countries which had been examined and these countries had a different type of laws, institutional environment and financial respectively. Therefore, findings conclude that liquidity and share price 
INTERNATIONAL JOURNAL OF ACADEMIC RESEARCH IN ACCOUNTING, FINANCE AND MANAGEMENT SCIENCES

Vol. 11, No. 2, 2021, E-ISSN: 2225-8329 @ 2021 HRMARS

performance were significantly negatively correlated to leverage for all countries, indicating that corporations prefer to apply its liquid assets to finance its investments rather than to use debt.

Moreover, Alipour et al (2015) in their study show mixed results regarding the effect of liquidity and capital structure. Finding results state that liquidity variables (current ratio) are positive associating to short term debt ratio, but negative connecting to long term debt ratio. It explained on how liquid firms more favor internal resources for financing purpose, in which it matches to POT method. As a result, the reason for negative liquidity relationship in Iran because of firms favour to utilizing its liquid assets to finance its investment in the situation of external debt rising. This result is supported and consistent with Hussain et al (2015), which their findings find that liquidity is significant and negative correlated with total debt ratio. Thus, the testable hypotheses for this study are.

H4a: Liquidity is negatively related to short term debt ratio of surviving family and surviving nonfamily companies.

H4b: Liquidity is negatively related to long term debt ratio of surviving family and surviving non-family companies.

H4c: Liquidity is negatively related to debt ratio of surviving family and surviving non-family companies.

\section{Methodology and Data Samples Selection}

Data from year 2000 to 2015 was selected, which consisted of total 16 years of data collected from Datastream and company annual report, considered sufficient to be used to investigate the relationship of determinants of capital structure to short term, long term debt and total debt ratio. Based on Gorriz and Fumas (2005), they define the surviving listed companies that can remain or maintain listed in the stock market for at least 15 years continuously. Besides that, this study collects the data started from the year 2000 just after the recovery of Malaysian economy from the financial crisis in 1998. The economic problems in Malaysia are considered lesser if compared to other countries example like Thailand, Indonesia and Korea (Weller, 1998). 
INTERNATIONAL JOURNAL OF ACADEMIC RESEARCH IN ACCOUNTING, FINANCE AND

MANAGEMENT SCIENCES

Vol. 11, No. 2, 2021, E-ISSN: 2225-8329 @ 2021 HRMARS

Table 1: Description of Data Sample from Main Board Companies Year 2000-2015

\begin{tabular}{lc}
\hline \multicolumn{1}{c}{ Description of Selected Companies } & $\begin{array}{c}\text { Number of } \\
\text { Surviving Listed } \\
\text { Companies }\end{array}$ \\
\hline \multicolumn{2}{c}{ Total companies listed in KLSE main market as at } \\
Year 2000 \\
Minus: Finance related companies \\
Minus: Companies fall in (PN4, PN17, delisted, non- \\
survived) & 474 \\
Minus: Companies with incomplete data & 219 \\
\hline Final sample for the study & 59 \\
\hline Surviving Family listed companies & 151 \\
\hline Surviving Non-Family listed companies & 72 \\
\hline
\end{tabular}

Table 1 summarizes the sample selection procedures. The selections of the samples in this study were considered as following selection process. The process initially considered all the companies listed in Kuala Lumpur Composite Index (KLCl) which listed on the main board only in year 1999. There are a total number of 474 listed companies on the Main Board of Bursa Malaysia as at 31 December 1999. The final sample for the study are 151 surviving listed companies consists of 72 surviving family firms and 79 surviving non-family firms.

\section{Dependent Variables}

\section{Debt Ratio}

Debt ratio is measured by the total debt divided by the total asset (Alipour et al., 2015; Chadha and Sharma, 2015; Hussain et al., 2015; Ahsan et al., 2016). The total debt includes both the short term and long term interest of debt financed by listed company as shown below:

Debt Ratio (DR) $=\frac{\sum \text { TotalDebt }}{\sum \text { TotalAsset }}$

Whereby: DR = Debt Ratio; $\Sigma$ Total Debt $=$ Total Debt; $\Sigma$ Total Asset $=$ Total Asset

\section{Short Term Debt Ratio}

Short term debt ratio is measured by the short term debt divided by the total asset (Alipour et al., 2015; Ahsan et al., 2016; Ohman and Tazdanfar, 2017) as shown below:

Short Term Debt Ratio (STDR) $=\frac{\sum \text { ShortTermDebt }}{\sum \text { TotalAsset }}$

Whereby: STDR = Short Term Debt Ratio; $\Sigma$ Short Term Debt = Total Short Term Debt;

$\sum$ Total Asset $=$ Total Asset 
INTERNATIONAL JOURNAL OF ACADEMIC RESEARCH IN ACCOUNTING, FINANCE AND

MANAGEMENT SCIENCES

Vol. 11, No. 2, 2021, E-ISSN: 2225-8329 @ 2021 HRMARS

\section{Long Term Debt Ratio}

Long term debt ratio is measured by the long term debt divided by the total asset (Alipour et al., 2015; Ahsan et al., 2016; Ohman and Tazdanfar, 2017) as shown below:

Long Term Debt Ratio (LTDR) $=\frac{\sum \text { LongTermDebt }}{\sum \text { TotalAsset }}$

Whereby: LTDR = Long Term Debt Ratio; $\Sigma$ Long Term Debt = Total Long Term Debt; $\quad \sum$ Total Asset $=$ Total Asset

\section{Independent Variables}

\section{Asset Tangibility}

Asset Tangibility is the total fixes asset divided by the total asset (Cekrezi, 2013; Chadha and Sharma, 2015; Alipour et al., 2015; Hussain et al., 2015; Ahsan et al., 2016; Ohman and Tazdanfar, 2017) given as follows:

Asset Tangibility (TANG) $=\frac{\sum F A_{1}}{\sum A_{1}}$

Whereby: TANG $=$ Asset Tangibility; $\sum F A_{1}=$ Total Fixed Asset; $\sum A_{1}=$ Total Asset

\section{Growth Opportunities}

Growth Opportunities is defined by annual percentage change of total asset (Chadha and Sharma, 2015; Alipour et al., 2015; Hussain et al., 2015; Ahsan et al., 2016; Ohman and Tazdanfar, 2017) given as follows:

Growth Opportunity (GROWTH) $=\frac{\left(\sum T A_{1}-\sum T A_{0}\right)}{\sum T A_{0}} X 100$

Whereby: GROWTH = Growth Opportunities; $\Sigma \mathrm{TA}_{1}=$ Total Asset for current year;

$\Sigma T A_{0}=$ Total Asset for previous year

\section{Profitability}

Profitability is the ratio of the earnings before interest and taxes (EBIT) to total assets (Cekrezi, 2013; Chadha and Sharma, 2015; Alipour et al., 2015; Hussain et al., 2015; Ahsan et al., 2016; Ohman and Tazdanfar, 2017) stated as follows:

Profitability $(\mathrm{PROF})=\frac{\mathrm{EBIT}_{1}}{\sum A_{1}}$

Whereby: $\mathrm{PROF}=$ Profitability; $\mathrm{EBIT}_{1}=$ Earnings Before Interest and Taxes;

$\sum \mathrm{A}_{1}=$ Total Asset

\section{Liquidity}

Liquidity is the ratio of current assets to current liabilities will be used in this study (Cekrezi, 2013; Chadha and Sharma, 2015; Alipour et al., 2015; Hussain et al., 2015; Ahsan et al., 2016; Ohman and Tazdanfar, 2017) stated as follows: 
INTERNATIONAL JOURNAL OF ACADEMIC RESEARCH IN ACCOUNTING, FINANCE AND

MANAGEMENT SCIENCES

Vol. 11, No. 2, 2021, E-ISSN: 2225-8329 @ 2021 HRMARS

Liquidity (LIQ) $=\frac{\sum C A}{\sum C L}$

Whereby: $\mathrm{LIQ}=$ Liquidity; $\Sigma \mathrm{CA}=$ Total Current Assets; $\Sigma \mathrm{CL}=$ Total Current Liabilities

\section{Regression Model}

The regression model (panel data analysis) for this study has shown as below.

Leverage $=\alpha+\beta_{1}$ TANG $+\beta_{2}$ GROWTH $+\beta_{3}$ PROF $+\beta_{4}$ LIQ $+\beta_{5}$ SIZE $+\mu$

Whereby:

Leverage $=$ Short term debt ratio, Long term debt ratio, Debt Ratio

$\alpha=$ Intersect

TANG = Asset Tangibility

GROWTH = Growth Opportunities

PROF $=$ Profitability

$\mathrm{LIQ}=$ Liquidity

SIZE $=$ Firm Size

$\mu=$ Error Term

Due to the merits of concerning time-series analyses and cross-section factor, panel data analysis will be used to estimate the above model. There are three possible variations of panel data analysis which are ordinary least square (OLS), the fixed effects model (FEM) and the random effects model (REM) in the panel data analysis. After the Hausmans test, the FEM is more appropriate to be used in this study.

\section{Results and Discussions}

\section{Descriptive Statistics}

Table 3 displays the descriptive statistics reports of the dependent and independent variables from the year 2000 to 2015, with 151 full samples of surviving companies. There are 72 surviving family firms and 79 surviving non-family firms had been identified for this study. The computed results comprise of min, max, mean and standard deviation of the variables for debt ratio (DR), short term debt ratio (STDR), long term debt ratio (LTDR), asset tangibility (TANG), growth opportunities (GROWTH), profitability (PROF), liquidity (LIQ) and control variable as firm size (SIZE) for full complete samples of surviving family and non-family listed companies in Malaysia.

The descriptive statistics present an average mean value and standard deviation value of debt ratio for the full sample is 21.8 percent and 0.140 respectively. Whereas, average mean value for surviving family is 21.7 percent and standard deviation value is 0.144 respectively. Mean and standard deviation value for surviving non-family is 21.9 percent and 0.137 respectively. Therefore, the mean value for short term debt ratio of full sample is 10.3 percent and standard deviation is 0.085 , mean value for family firms is 10.6 percent and standard deviation is 0.087 and non-family firms is 10.0 percent and standard deviation is 0.108 . By examining long term debt ratio, mean for full sample is 11.6 percent and standard deviation is 0.105 , whereby surviving family firm is 11.1 percent and 
INTERNATIONAL JOURNAL OF ACADEMIC RESEARCH IN ACCOUNTING, FINANCE AND MANAGEMENT SCIENCES

Vol. 11, No. 2, 2021, E-ISSN: 2225-8329 @ 2021 HRMARS

standard deviation is 0.104 , and surviving non-family firm is 12.0 percent and standard deviation is 0.107 respectively. Overall, the results show that the leverage for surviving family firms are slightly lower than surviving non-family firms.

Furthermore, maximum value for total debt ratio in the research full sample is 55.8 percent, whereby family firm is 55.7 percent and non-family firm is 55.8 percent. Maximum value for short term debt ratio is 38.5 percent for full sample, while family firm is 38.5 percent and non-family firm is 35.0 percent. Meanwhile, maximum value for long term debt ratio for full sample is 53.7 percent, family firm is $\mathbf{4 7 . 7}$ percent and non-family firm is $\mathbf{5 3 . 7}$ percent. It is obvious that surviving non-family firms' leverages are slightly higher than family firms as comparison, which indicates that surviving family firms have lesser debt as compared to surviving non-family firms in adopting long term debt and debt ratio. Succinctly, the mean value of the short term debt for family firms (10.6 percent) is slightly larger than non-family firms (10.0 percent). This indicates that family ownership debt level is lower than non-family ownership in comparison (Gorriz and Fumas, 1996; Mishra et al., 2001; Anderson and Reeb, 2003; Sraer and Thesmar, 2006).

Table 3: Descriptive Statistics for Surviving Listed Companies in Malaysia for year 2000 until 2015

\begin{tabular}{|c|c|c|c|c|c|c|c|c|c|c|c|c|}
\hline \multirow[b]{2}{*}{ Variables } & \multicolumn{4}{|c|}{ Full Sample (151) } & \multicolumn{4}{|c|}{ Surviving Family (72) } & \multicolumn{4}{|c|}{ Surviving Non-Family (79) } \\
\hline & Mean & $\begin{array}{c}\text { Standard } \\
\text { Deviation }\end{array}$ & Min & Max & Mean & $\begin{array}{l}\text { Standard } \\
\text { Deviation }\end{array}$ & Min & $\operatorname{Max}$ & Mean & $\begin{array}{l}\text { Standard } \\
\text { Deviation }\end{array}$ & Min & Max \\
\hline DR & 0.218 & 0.140 & 0.000 & 0.558 & 0.217 & 0.144 & 0.000 & 0.557 & 0.219 & 0.137 & 0.000 & 0.558 \\
\hline STDR & 0.103 & 0.085 & 0.000 & 0.385 & 0.106 & 0.087 & 0.000 & 0.385 & 0.100 & 0.1084 & 0.000 & 0.350 \\
\hline LTDR & 0.116 & 0.105 & 0.000 & 0.537 & 0.111 & 0.104 & 0.000 & 0.477 & 0.120 & 0.107 & 0.000 & 0.537 \\
\hline TANG & 0.411 & 0.172 & 0.038 & 0.857 & 0.410 & 0.156 & 0.072 & 0.857 & 0.411 & 0.187 & 0.038 & 0.834 \\
\hline GROWTH & 9.187 & 11.272 & -9.821 & 59.316 & 8.100 & 8.487 & -6.198 & 52.582 & 10.177 & 13.292 & -9.821 & 59.316 \\
\hline PROF & 0.068 & 0.789 & -0.070 & 0.689 & 0.064 & 0.047 & -0.028 & 0.332 & 0.072 & 0.100 & -0.070 & 0.689 \\
\hline LIQ & 3.053 & 3.228 & 0.570 & 21.351 & 3.464 & 3.737 & 0.812 & 21.351 & 2.679 & 2.651 & 0.570 & 14.413 \\
\hline SIZE & 13.871 & 1.350 & 11.265 & 18.0935 & 13.913 & 1.348 & 11.503 & 17.305 & 13.833 & 1.359 & 11.265 & 18.094 \\
\hline ASSETS & $3,541,379$ & $8,392,637$ & 98,796 & $74,241,075$ & $3,541,533$ & $7,245,601$ & 102,584 & $38,383,275$ & $3,541,239$ & $9,363,079$ & 98,796 & $74,241,075$ \\
\hline
\end{tabular}

On the other hand, the asset tangibility full sample mean and standard deviation value is 41.1 percent and 0.172 , indicates that all company's fixed assets are 41.1 percent of total assets, whereby family firms sample mean and standard deviations values are 41.0 percent and 0.156 , which indicates that surviving family firms fixed assets are about 41.0 percent out of total assets. While for non-family the asset tangibility mean and standard deviations are at the value of 41.1 percent and 0.187 , which shows that surviving non-family's fixed assets are 41.1 percent out of total assets. Indeed, the mean value for asset tangibility for all group of samples are almost the same value, but the surviving family companies are slightly less risky than surviving non-family firm in managing their fixed asset as collateral.

In addition, the average growth opportunities of surviving full sample firms during the observation period are 9.187 percent and standard deviation is 11.272 . The average growth opportunities and standard deviation for surviving family is 8.1 percent and 8.487 , non-family is 10.177 percent and 13.292. As stated in the data, in term of the percentage of growth opportunities, surviving non-family firm is 10.177 percent growing better and higher than surviving family firms. 
INTERNATIONAL JOURNAL OF ACADEMIC RESEARCH IN ACCOUNTING, FINANCE AND MANAGEMENT SCIENCES

Vol. 11, No. 2, 2021, E-ISSN: 2225-8329 @ 2021 HRMARS

Besides, the full sample for surviving firms are only able to make average profit of 6.8 percent by utilizing their total assets and standard deviation is 0.789 . However, surviving family firms can generate average profit of 6.4 percent from total assets and standard deviation is 0.047 is less profitable than surviving non-family firms with 7.2 percent average profit and the standard deviation is 0.100 .

On the other hand, the average liquidity shows that surviving full sample firms current assets are 3 times (mean value is 3.053) more than it current liabilities and the standard deviation is 3.228. Besides, the average liquidity of surviving family firm is 3 times (mean value is 3.464) and the standard deviation is 3.737, for surviving non-family is 2 times (mean value is 2.679 ) and the standard deviation is 2.651. In addition, the descriptive statistics table also show an average value of firm size (total assets) for all surviving firms' amounts are RM3,541.379 million and standard deviation are RM8,392.637 million. However, surviving family firms are slightly larger than surviving non-family firms nevertheless, it still categories as a large firm size with average total assets of RM3,541.533 million and standard deviation are RM7,245.601 million as compared to surviving non-family RM3,541.239 million and standard deviation are RM9,363.079 million respectively.

Table 4: Differences of Means (Independent T-Tests)

\begin{tabular}{lccc}
\hline \multicolumn{1}{c}{ Variables } & $\begin{array}{c}\text { Non-Family } \\
\mathbf{( 7 9 )} \\
\text { Mean }\end{array}$ & $\begin{array}{c}\text { Family (72) } \\
\text { Mean }\end{array}$ & t-statistics \\
\hline Dependent Variable & & & \\
Debt Ratio (DR) & 0.219 & 0.217 & 0.097 \\
Short Term Debt Ratio (STDR) & 0.100 & 0.106 & -0.441 \\
Long Term Debt Ratio (LTDR) & 0.120 & 0.111 & 0.528 \\
& & & \\
Independent Variables & & & \\
Asset Tangibility (TANG) & 0.411 & 0.410 & 0.058 \\
Growth Opportunity (GROWTH) & 10.177 & 8.100 & $1.154^{* * *}$ \\
Profitability (PROF) & 0.0723 & 0.064 & $1.680^{* * *}$ \\
Liquidity (LIQ) & 2.679 & 3.464 & -1.499 \\
Firm Size (SIZE)[In(Total Asset)] & 13.833 & 13.913 & -0.367 \\
\hline
\end{tabular}

$* * *$ significant at 0.01 level. ${ }^{* *}$ significant at 0.05 level.

Referring to Table 4, the dependent variables are insignificant differences in the mean between surviving family and non-family firms. The t-test shows that there is no evidence of significant difference between them in term of all leverages. The unique components are the growth opportunities and profitability, the only mean value between family and non-family shows a significant difference. The average mean value of growth opportunities for surviving family firms are 8.10 percent and surviving non-family firms are 10.177 percent. Family and non-family firms are found a statistically significant difference in mean at 1 percent level as shown in Table 4.2 with tstatistics value 1.154. Thus, the growth opportunities for non-family firms are slightly better than family firms. Furthermore, non-family ownership outperforms than family ownership with a greater valuation in term of profitability. The mean value for the full sample is 6.8 percent, family firms is 6.4 
INTERNATIONAL JOURNAL OF ACADEMIC RESEARCH IN ACCOUNTING, FINANCE AND MANAGEMENT SCIENCES

Vol. 11, No. 2, 2021, E-ISSN: 2225-8329 @ 2021 HRMARS

percent and non-family firms are 7.2 percent. As shown in Table 4.2, it is found statistically significant difference in mean at 1 percent level on profitability for family and non-family firms, with t-statistics value 1.680 . So, non-family firms are capable to generate much higher profit as compared to family firms. However, family and non-family firms are commonly no difference in term of debt ratio, short term debt ratio, long term debt ratio, asset tangibility, liquidity and firm size.

\section{Pearson's Correlation Matrix}

According to correlations between study variables as depicted in Table 5, liquidity $(r=-0.477, p<0.01)$ and firm size $(r=0.309, p<0.01)$ have negative and positive relation to debt ratio respectively. In addition, profitability $(r=-0.223, p<0.01)$ and liquidity $(r=-0.403, p<0.01)$ correlate with short term debt ratio in negative manner. Meanwhile, liquidity $(r=-0.313, p<0.01)$ and firm size $(r=0.489, p<0.01)$ are negative and positive relation to long term debt ratio respectively.

Table 5: Pearson's Correlation Matrix

\begin{tabular}{|c|c|c|c|c|c|c|c|c|}
\hline $\begin{array}{l}\text { Variable } \\
s\end{array}$ & DR & STDR & LTDR & TANG & $\begin{array}{c}\text { GROWT } \\
\mathrm{H}\end{array}$ & PROF & LIQ & SIZE \\
\hline DR & 1 & & & & & & & \\
\hline STDR & $0.663^{* *}$ & 1 & & & & & & \\
\hline LTDR & $0.800 * *$ & 0.082 & 1 & & & & & \\
\hline TANG & 0.047 & -0.002 & 0.067 & 1 & & & & \\
\hline $\begin{array}{l}\text { GROWT } \\
\mathrm{H}\end{array}$ & -0.038 & -0.091 & 0.025 & -0.044 & 1 & & & \\
\hline PROF & -0.147 & $\begin{array}{c}- \\
0.223^{*} \\
*\end{array}$ & -0.020 & -0.107 & -0.038 & 1 & & \\
\hline LIQ & $\begin{array}{c}- \\
0.477^{* *}\end{array}$ & $\begin{array}{c}- \\
0.403^{*} \\
*\end{array}$ & $0.313^{* *}$ & $\begin{array}{c}- \\
0.179 \\
*\end{array}$ & 0.071 & -0.05 & 1 & \\
\hline SIZE & $0.309 * *$ & -0.107 & $0.489^{* *}$ & 0.125 & 0.018 & 0.151 & $\begin{array}{c}- \\
0.267^{*} \\
*\end{array}$ & 1 \\
\hline
\end{tabular}

** Correlation is significant at the 0.01 level (2-tailed).

* Correlation is significant at the 0.05 level (2-tailed).

Note: Debt ratio (DR), short term debt ratio (STDR), long term debt ratio (LTDR), asset tangibility (TANG), growth opportunities (GROWTH), profitability (PROF), liquidity (LIQ) and control variable as firm size (SIZE)

\section{The Multiple Regression Model}

Table 6 exhibits that all the capital structure determinants as proxied by asset tangibility (TANG), growth opportunities (GROWTH), profitability (PROF), liquidity (LIQ), and firm size (SIZE) are negative and positive significant to debt ratio at 1 percent and 5 percent level respectively. 
INTERNATIONAL JOURNAL OF ACADEMIC RESEARCH IN ACCOUNTING, FINANCE AND MANAGEMENT SCIENCES

Vol. 11, No. 2, 2021, E-ISSN: 2225-8329 @ 2021 HRMARS

Table 6: Regression results of the fixed effect model by using short term debt

\begin{tabular}{|c|c|c|c|c|}
\hline Variables & $\begin{array}{l}\text { Expected } \\
\text { Sign }\end{array}$ & Full Sample & Family & Non-Family \\
\hline Intercept & & $\begin{array}{c}0.052 \\
(1.042) \\
\end{array}$ & $\begin{array}{c}-0.101 \\
(-1.504) \\
\end{array}$ & $\begin{array}{c}0.145 \\
(2.012)^{* *}\end{array}$ \\
\hline TANG & - & $\begin{array}{c}0.016 \\
(1.322) \\
\end{array}$ & $\begin{array}{c}0.077 \\
(4.435)^{* * *}\end{array}$ & $\begin{array}{c}-0.019 \\
(-1.096)\end{array}$ \\
\hline GROWTH & - & $\begin{array}{c}-0.00006 \\
(-1.586)\end{array}$ & $\begin{array}{c}0.00002 \\
(0.365)\end{array}$ & $\begin{array}{c}-0.00006 \\
(-1.468)\end{array}$ \\
\hline PROF & - & $\begin{array}{c}-0.210 \\
(-8.925)^{* * *}\end{array}$ & $\begin{array}{c}-0.262 \\
(-7.149) * * *\end{array}$ & $\begin{array}{l}-0.189 \\
(-6.026)^{* * *}\end{array}$ \\
\hline LIQ & - & $\begin{array}{c}-0.006 \\
(-12.506)^{* * *}\end{array}$ & $\begin{array}{l}-0.006 \\
(-8.137)^{* * *}\end{array}$ & $\begin{array}{l}-0.006 \\
(-8.795)^{* * *}\end{array}$ \\
\hline SIZE & + & $\begin{array}{c}0.006 \\
(1.611) \\
\end{array}$ & $\begin{array}{c}0.015 \\
(3.280)^{* * *}\end{array}$ & $\begin{array}{l}-0.0004 \\
(-0.088) \\
\end{array}$ \\
\hline Observation & & 2416 & 1152 & 1264 \\
\hline$R^{2}$ & & 0.601 & 0.684 & 0.544 \\
\hline Adj $R^{2}$ & & 0.574 & 0.661 & 0.512 \\
\hline F-stat(p-value) & & $21.518(0.000)$ & $30.577(0.000)$ & $16.937(0.000)$ \\
\hline
\end{tabular}

(DR), short term debt ratio (STDR), long term debt ratio (LTDR), asset tangibility (TANG), growth opportunities (GROWTH), profitability (PROF), liquidity (LIQ), control variable as firm size (SIZE). Value in the parentheses ( ) is the t-statistic value.

Asset tangibility of surviving family firms shows a significant positive relationship with short term debt at 1 percent level and they tend to use short term debt to finance their capital for operation. Therefore, the results for surviving non-family firms consistent with Abor and Biekpe (2009); Al-Ajmi et al (2009); Song (2005); Buferna, Bangassa, Hodgkinson (2008); Cekrezi (2013); Ahsan et al. (2016); Ohman and Yazdanfar (2017) and do not support H1a hypothesis for both surviving family and nonfamily firms.

On the other hand, for growth opportunities, the results show an insignificant negative relationship for full and surviving non-family which do not support $\mathrm{H} 2 \mathrm{a}$ hypothesis. This finding is consistent with Abor and Biekpe (2009); Ahsan et al. (2016) that find growth and short term debt are negatively related. Furthermore, Song (2005) states a negative relationship between growth opportunities and all measurements of capital structure (short term, long term, debt ratio), which is statistically significant and consistent with the TOT (Alipour et al., 2015). However, growth opportunities for family firms show an insignificant positive relationship with short term debt, which also do not support $\mathrm{H} 2 \mathrm{a}$ hypothesis.

Interestingly, profitability for all three category groups (full sample, surviving family and non-family) are significantly negatively related to short term debt at 1 percent level and supports $\mathrm{H} 3$ a hypothesis. Based on pecking order theory, firms will prefer to finance from retained earnings first, then only 
INTERNATIONAL JOURNAL OF ACADEMIC RESEARCH IN ACCOUNTING, FINANCE AND MANAGEMENT SCIENCES

Vol. 11, No. 2, 2021, E-ISSN: 2225-8329 @ 2021 HRMARS

proceed to debt and finally by issuing new equity to acquire more capital. Such theory suggests a negative relationship between profitability and debt ratios (Myers and Majluf, 1984). Empirically, most of the empirical studies support the POT. Such relationship of empirical statistically results is consistent and in line with all these empirical studies, namely (Yammeesri and Lodh, 2004; Yeh et al., 2001; Titman and Wessels, 1988; Kester, 1986; Friend and Lang, 1988; Faris Mouamer, 2011; Qiu and La, 2010; Al-Ajmi et al., 2009; Abor and Biekpe, 2009; Mazhar and Nasr, 2010; Chen and Strange, 2005; Cekrezi, 2013; Alipour et al., 2015; Frank and Goyal, 2009; Ohman and Yazdanfar 2017). Thus, it is concluded that more profitable firms shall use their internal funds which is retained earnings to finance their business activities as a priority, so resulting firms borrowing less as compared to less profitable firms, consistent with the POT.

Furthermore, liquidity for all groups are significant and negative relationship to short term debt at 1 percent level and support $\mathrm{H} 4 \mathrm{a}$ hypothesis. The results are supported by empirical studies of Faris Mouamer (2011); Al-Ajmi et al. (2009); Ahsan et al. (2016); Ohman and Yazdanfar (2017), but inconsistent with Alipour et al. (2015) which stated liquidity is positively related to short term debt ratio. As a result, the liquidity for all groups shall decrease when short term debt among them are increasing or in another word, these full sample, surviving family and non-family firms with higher liquidity pay off short term debts by using the liquid assets. It is also in line with POT as well as static TOT.

Table 7 exhibits that all the capital structure determinants as proxied by asset tangibility (TANG), growth opportunities (GROWTH), profitability (PROF), liquidity (LIQ), and firm size (SIZE) are negative and positive significant to long term debt ratio at 1 percent and 5 percent level respectively. Asset tangibility for all categories estimated coefficient are proved to have a significant positive relationship with long term debt, and all groups are significantly at 1 percent level, support H1b hypothesis. Both family and non-family firms' long term debt shall increase in consistent with the increasing of asset tangibility. Furthermore, family and non-family companies are preferred to use long term debt to finance their fixed assets. Such finding results also in line and supported by Abor and Biekpe (2009); Song (2005); Buferna, Bangassa, Hodgkinson (2008); Cekrezi (2013)' Alipour et al. (2015); Ahsan et al. (2016); Ohman and Yazdanfar (2017). However, such findings are inconsistent with Al-Ajmi et al. (2009) that tangibility significantly negative for debt ratio and long term and explained that firms do not finance long term asset with long term debt. 
INTERNATIONAL JOURNAL OF ACADEMIC RESEARCH IN ACCOUNTING, FINANCE AND MANAGEMENT SCIENCES

Vol. 11, No. 2, 2021, E-ISSN: 2225-8329 @ 2021 HRMARS

Table 7: Regression results of the fixed effect model by using long term debt

\begin{tabular}{lcccc}
\hline \multicolumn{1}{c}{ Variables } & $\begin{array}{c}\text { Expected } \\
\text { Sign }\end{array}$ & Full Sample & Family & Non-Family \\
\hline Intercept & & $\begin{array}{c}-0.727 \\
(-13.035)^{* * *}\end{array}$ & $\begin{array}{c}-0.979 \\
(-12.907)^{* * *}\end{array}$ & $\begin{array}{c}-0.572 \\
(-7.149)^{* * *}\end{array}$ \\
\hline TANG & + & 0.125 & 0.150 & 0.121 \\
& & $(9.179)^{* * *}$ & $(7.615)^{* * *}$ & $(6.332)^{* * *}$ \\
\hline GROWTH & + & 0.0002 & 0.0003 & 0.0002 \\
& & $(4.343)^{* * *}$ & $(3.911)^{* * *}$ & $(3.106)^{* * *}$ \\
\hline PROF & - & -0.022 & 0.065 & -0.056 \\
& & $(-0.849)$ & $(1.556)$ & $(-1.615)$ \\
\hline LIQ & - & 0.0005 & 0.002 & -0.0004 \\
& & $(0.853)$ & $(2.698)^{* * *}$ & $(-0.487)$ \\
\hline SIZE & & 0.057 & 0.073 & 0.047 \\
& & $(14.512)^{* * *}$ & $(13.879)^{* * *}$ & $(8.223)^{* * *}$ \\
\hline Observation & & 2416 & 1152 & 1264 \\
\hline $\mathrm{R}^{2}$ & & 0.647 & 0.711 & 0.605 \\
\hline Adj ${ }^{2}$ & 0.623 & 0.691 & 0.577 \\
\hline F-stat (p-value) & & $26.750(0.000)$ & $34.794(0.000)$ & $21.744(0.000)$ \\
\hline$* *$ significant at 0.01 level. ${ }^{* *}$ significant at 0.05 level. & $*$ significant at 0.10 level
\end{tabular}

Note: Debt ratio (DR), short term debt ratio (STDR), long term debt ratio (LTDR), asset tangibility (TANG), growth opportunities (GROWTH), profitability (PROF), liquidity (LIQ), control variable as firm size (SIZE). Value in the parentheses ( ) is the t-statistic value.

Meanwhile, the growth opportunities also found to be statistically significant at 1 percent level and positively related with all of the three groups and support $\mathrm{H} 2 \mathrm{~b}$ hypothesis. This findings support Abor and Biekpe (2009); Ahsan et al. (2016); and Ohman and Yazdanfar (2017) which found that growth and long term debt have positive relationship showing that these surviving family firms with a relatively high growth rate are preferring to use more external financing. In contrary, Song's (2005) study found that there was no relationship between leverage with expected growth. Similarly, these finding results are inconsistent with Faris Mouamer (2011); and Alipour et al. (2015) studies, which claim growth opportunities are negatively correlated to long term debt and not in line with the TOT.

Moreover, the findings show that all groups are insignificant related to long term debt for profitability, with full sample and non-family firms negatively related to long term debt. These findings are inconsistent with most of the empirical studies such as Qiu and La (2010) Al-Ajmi et al. (2009); Abor and Biekpe (2009); Mazhar and Nasr (2010); Faris Mouamer (2011); Cekrezi (2013); Alipour et al. (2015); Frank and Goyal (2009); Ahsan et al. (2016); Ohman and Yazdanfar (2017). This finding result do not support $\mathrm{H} 3 \mathrm{~b}$ hypothesis, although surviving family firms had a positive relationship with long term debt. Thus, the result showed that there is no significant between profitability and long term debt for surviving firms in Malaysia. Liquidity, as measured by current ratio, are found significant and positively related to long term debt at 1 percent significance level for surviving family firms and supported by Ahsan et al. (2016). However, it is not support H4b 
INTERNATIONAL JOURNAL OF ACADEMIC RESEARCH IN ACCOUNTING, FINANCE AND MANAGEMENT SCIENCES

Vol. 11, No. 2, 2021, E-ISSN: 2225-8329 @ 2021 HRMARS

hypothesis. Although liquidity for full sample and surviving non-family ownership are found insignificant positive and negative relationship with long term debt respectively, thus do not support $\mathrm{H} 4 \mathrm{~b}$. Relationship of non-family liquidity negatively related to long term debt is in line with the study of Al-Ajmi et al. (2009); Alipour et al. (2015); Ohman and Yazdanfar (2017).

The study has also analyzed the relationship between firm size and long term debt. It was found that for all three groups are all are significant and positive in relation to long term debt at 1 percent level. This finding shows that both surviving family and non-family firms' size both were increasing together with the increasing of their long term debt. Thus, it is found to be consistent with Titman and Wessels, 1988; Rajan and Zingales, 1995; Daskalakis and Psillaki, 2008; Abor and Biekpe, 2009; Chen and Strange, 2005; Alipour et al., 2015; Cekrezi, 2013; Ahsan et al., 2016). The results imply that larger firms are more diversified and are perceived to have lower risk and it is also consistent with trade-off theory and agency cost indicating that the larger firms experience lower agency costs of debt.

Table 8 exhibits that all the capital structure determinants as proxied by asset tangibility (TANG), growth opportunities (GROWTH), profitability (PROF), liquidity (LIQ), and firm size (SIZE) are negative and positive significant to debt ratio at 1 percent and 5 percent level respectively.

Table 8: Regression results of the fixed effect model by using debt ratio

\begin{tabular}{lcccc}
\hline \multicolumn{1}{c}{ Variables } & $\begin{array}{c}\text { Expected } \\
\text { Sign }\end{array}$ & Full Sample & Family & Non-Family \\
\hline Intercept & & -0.700 & -1.080 & -0.469 \\
& + & 0.145 & $(-10.987)^{* * *}$ & $(-5.091)^{* * *}$ \\
\hline TANG & & 0.226 & 0.107 \\
& + & 0.0001 & 0.0003 & $(4.882)^{* * *}$ \\
\hline GROWTH & & $(2.447)^{* *}$ & $(3.268)^{* * *}$ & 0.00009 \\
& - & -0.231 & -0.198 & -0.244 \\
\hline PROF & - & -0.006 & -0.004 & $(-6.080)^{* * *}$ \\
\hline LIQ & & $(-8.497)^{* * *}$ & $(-3.465)^{* * *}$ & -0.007 \\
& & 0.064 & 0.088 & 0.049 \\
\hline SIZE & + & $(13.563)^{* * *}$ & $(12.948)^{* * *}$ & $(7.500)^{* * *}$ \\
\hline Observation & & 2416 & 1152 & 1264 \\
\hline $\mathrm{R}^{2}$ & & 0.692 & 0.737 & 0.659 \\
\hline Adj R & & 0.671 & 0.719 & 0.635 \\
\hline F-stat(p-value) & & $32.759(0.000)$ & $39.697(0.000)$ & $27.482(0.000)$ \\
\hline
\end{tabular}

$* * *$ significant at 0.01 level. ${ }^{* *}$ significant at 0.05 level. ${ }^{*}$ significant at 0.10 level Note: Debt ratio (DR), short term debt ratio (STDR), long term debt ratio (LTDR), asset tangibility (TANG), growth opportunities (GROWTH), profitability (PROF), liquidity (LIQ), control variable as firm size (SIZE). Value in the parentheses ( ) is the t-statistic value. 
INTERNATIONAL JOURNAL OF ACADEMIC RESEARCH IN ACCOUNTING, FINANCE AND MANAGEMENT SCIENCES

Vol. 11, No. 2, 2021, E-ISSN: 2225-8329 @ 2021 HRMARS

Interestingly, asset tangibility for all of the three group are found to be significant and positive related to debt ratio at 1 percent level, hence support H1c. The results are in line with studies of Titman and Wessels (1988); Harris and Raviv (1990); Long and Maltiz (1985); Friend and Lang (1988); Rajan and Zingales (1995); Wald (1999); Williamson (1988); Harris and Raviv (1990); Qiu and La (2010); Al-Najjar and Taylor (2008); Seppa (2008); Cekrezi (2013); Chadha and Sharma (2015); Vergas et al. (2015), and Hussain et al. (2015). Hussain et al. (2015) who study the Malaysian case of asset tangibility is also found positively related to total debt ratio indicating that firms used their fixed assets as collaterals to finance debt.

Furthermore, all groups are positively related to total debt ratio for growth opportunities, with family firms show a significant relationship with total debt of 1 percent level. While the full sample group shows a positive significant relationship of 5 percent level. These two group support H2c hypothesis, however, non-family firms do not support $\mathrm{H} 2 \mathrm{c}$ hypothesis.

However, family firms are positively related to debt ratio and supported by Rao and Lukose (2002); Qiu and La (2010); Chadha and Sharma (2015); Vergas et al. (2015); Al-Najjar and Taylor (2008); Mazhar and Nasr (2010); Ahsan et al. (2016); Vergas et al. (2015), shows that higher growth opportunities indicate a higher demand for funds. However, Hussain et al. (2015) claim that growth opportunities are found to be positively insignificant with total debt ratio. Besides, finding result is inconsistent with Deesomsak et al. (2004); Song (2005) who concluded that growth does not significantly affect capital structure.

As for profitability, all groups are having a significant and negative relationship with debt ratio, which support $\mathrm{H} 3 \mathrm{c}$ hypothesis, with all groups having 1 percent significant level. It is proved that profitability for all groups are negatively related to total debt ratio. It is supported by pecking order theory and most empirical studies of Myers and Majluf (1984); Titman and Wessels (1988); Kester (1986); Friend and Lang (1988); Faris Mouamer (2011); Qiu and La (2010); Al-Ajmi et al. (2009); Abor and Biekpe (2009); Frank and Goyal (2009); Mazhar and Nasr (2010); Chen and Strange (2005); Cekrezi (2013); Alipour et al. (2015); Vergas et al. (2015); Chadha and Sharma (2015); and Hussain et al. (2015). As a result, it can be concluded that more profitable firms shall utilize internal funds first which is retained earnings to finance, resulting firms shall borrow less as compared to less profitable firms, which support the pecking order theory. On the other hand, the finding result is inconsistent to Deesomsak et al. (2004) claimed that corporate profitability was insignificantly affecting capital structure.

Furthermore, liquidity also shows a strong significant and negative relationship with total debt ratio, at 1 percent level for all groups. This finding results support $\mathrm{H} 4 \mathrm{c}$ hypothesis. It is consistent and in line with these studies, such as Al-Ajmi et al. (2009); Deesomsak et al. (2004); Mat Kila and Wan Mahmood (2008); Ahsan et al. (2016); Hussain et al. (2015). However, Chadha and Sharma (2015) study showed liquidity statistically insignificant and has a negative coefficient. In sum, such finding results are in line with pecking order theory as well as trade-off theory. Liquidity significantly negatively to leverage illustrated that both surviving family and non-family firms tend to use their liquid assets to finance their investments than to use debt. In addition, it also indicated that firms with high liquidity tend to use less debt and finance their investments following the pecking order theory for their longevity and to be sustained in the market. 
INTERNATIONAL JOURNAL OF ACADEMIC RESEARCH IN ACCOUNTING, FINANCE AND MANAGEMENT SCIENCES

Vol. 11, No. 2, 2021, E-ISSN: 2225-8329 @ 2021 HRMARS

Firm size is found to be significant at 1 percent level for all groups, positive relation for all the sampling group, however, this finding is inconsistent with Salwani et al. (2007) which found that firm size did not appear to have any significant effect on the capital structure in the Malaysian market. Firm size of surviving family and non-family firms are significantly positive related to debt ratio and in line with studies like Seppa (2008); Titman and Wessels (1988); Daskalakis and Psillaki (2008); Rajan and Zingales (1995); Harris and Raviv (1990); Bevan and Danbolt (2002); Pandey (2004); Wickramanayake (2009); Booth et al. (2001); Wald (1999); Qian and Wirjanto (2008); Vergas et al. (2015); Cekrezi (2013); Ahsan et al. (2016); Vergas et al. (2015) and consistent with trade-off theory indicate a positive relation between the two variables. Therefore, the larger firms may issue debt at lower costs and have easy access to the capital market compared to smaller firms. Also, larger firms experience lower agency costs of debt as well.

\section{Conclusions}

This main purpose of this paper is to examine the impact of assets tangibility, growth opportunities, profitability and liquidity on financial leverage as proxies by short term debt ratio, long term debt ratio and total debt ratio. Moreover, the uniqueness of this study is by taking the 151 surviving family and non-family public listed companies in Malaysia from year 2000 to 2015 (16 years) to be as a sample of the study. The findings show that all the capital structure determinants are significant either positively or negatively against the debt ratio, except growth opportunities which is insignificant for non-family firms.

Meanwhile, the findings of descriptive statistics show that mean value of debt ratio for surviving family firms (21.7\%) are slightly lower than surviving non-family firms (21.9\%) indicating family firms utilize slightly less debt as compared to non-family firms. Interestingly, growth opportunities and profitability showed significant difference between family firms and non-family firms and non-family firms report higher growth opportunities and profitability than family firms.

Conclusively, it had been statistically proven that surviving non-family companies perform slightly better than surviving family companies, in term of its asset tangibility, growth opportunities and profitability. However, surviving family companies' liquidity is slightly better than surviving nonfamily companies in comparison. In addition, surviving family firm's size also recorded slightly larger than surviving non-family and used lesser debts in comparison to surviving non-family companies in Malaysia. Based on these empirical findings, surviving companies prefer to use internal sources as their main priority for financial leverage decisions to sustain their business operation. Furthermore, the results reveal that surviving companies have enough liquid assets and can utilize these funds to finance business activities and expecting to have lower leverage (Al-Ajmi et al., 2009). As a result, surviving companies tend to manage their leverage wisely for the survival and longevity of the business operation in long run.

In summary, the implication and recommendation that should be highlighted here is way of making investors' decision in choosing the sustainable companies with the aim to maximize their return at a minimum risk level and make rational investment decisions. For practitioners such as financial managers should have the responsibility to ensure their firms are able to finance at the lowest possible cost and increase value for the firms by making financial decisions effectively and efficiently. 
INTERNATIONAL JOURNAL OF ACADEMIC RESEARCH IN ACCOUNTING, FINANCE AND

MANAGEMENT SCIENCES

Vol. 11, No. 2, 2021, E-ISSN: 2225-8329 @ 2021 HRMARS

Furthermore, they are able to make decision on when is the best time to utilize debt in which this could leads to the growth and future survival of the firm. On the other hand, given that the bankruptcy costs were very high, it will be appropriate with the low target capital structure setting. Furthermore, investors invest with the target to maximize their return at a minimum risk level. This study would provide better access for investors to make rational investment decisions. An investor can enjoy the advantage if they have the knowledge of capital structure. Suggestion for future research in the area of family ownership, the study recommends exploring the performance between the company managed by the founder and descendent of the family members as Chief Executive Officer (CEO). Hence, it is strongly believing that by examining the founder and descendent influence shall advance a deeper understanding of family ownership and its performance of the firm. It is a very interesting research topic and shall benefits academician, practitioner, and investor to have a better understanding on family firm.

\section{Acknowledgment}

The first author would like to thank Universiti Sains Malaysia for granting a Research University Grant (RUI), Grant No. 1001.PMGT.8016087.

\section{References}

Abor, J., and Biekpe, N. (2009). How do we explain the capital structure of SMEs in sub-Saharan Africa? Evidence from Ghana, Journal of Economic Studies, 36(1), 83-97.

Ahsan T., Wang, M., and Qureshi, M. A. (2016). Firm, industry, and country level determinants of capital structure: evidence from Pakistan, South Asian Journal of Global Business Research, 5(3), $362-384$.

Al-Ajmi, J., Hussain, H. A., and Al-Saleh, N. (2009). Decisions on capital structure in

a Zakat environment with prohibition of riba: The case of Saudi Arabia, The Journal of Risk Finance, 10(5), 460-476.

Al-Najjar, B., and Taylor, P. (2008). The relationship between capital structure and ownership structure, Managerial Finance, 34(12), 919-933.

Alipour, M., Mohammadi, M. F. S., and Derakhshan, H. (2015). Determinants of capital structure: An empirical study of firms in Iran. International Journal of Law and Management, 57(1), 53-83.

Ampenberger, M., Schmid, T., Achleitner, A., and Kaserer, C. (2013). Capital Structure Decisions in Family Firms: Empirical Evidence from a Bank-based Economy, Review of Managerial Science, 7(3), 247-275.

Anderson, R. C., and Reeb, D. M. (2003). Founding-Family Ownership and Firm Performance: Evidence from the S\&P 500, The Journal of Finance, 58(3), 1301-1328.

Baral, K. J. (2004). Determinants of Capital Structure: A Case Study of Listed Companies of Nepal, Journal of Nepalese Business Studies, 1(1), 1-13.

Berle, A. A., and Means, G. (1932). The Modern Corporation and Private Property, MacMillan, New York, N.Y.

Bertrand, M., and Schoar, A. (2006). The Role of Family in Family Firms, The Journal of Economic Perspectives, 20(2), 73-96.

Berzins, J., Bohren, O., and Stacescu, B. (2013). Tax concerns and agency concerns in dividend policy: Holding companies as a separating device, Working Paper No. 2/2013, Centre for Corporate Governance Research, BI Norwegian Business School, Norway. 
INTERNATIONAL JOURNAL OF ACADEMIC RESEARCH IN ACCOUNTING, FINANCE AND

MANAGEMENT SCIENCES

Vol. 11, No. 2, 2021, E-ISSN: 2225-8329 @ 2021 HRMARS

Bevan, A., and Danbolt, J. (2002). Capital Structure and its Determinants in the UK - A Deco Positional Analysis, Applied Financial Economics, 12, 159-170.

Blanco-Mazagatos, V., De Quevedo-Puente, E., and Castrillo, L. A. (2007). The Trade-off Between Financial Resources and Agency Costs in the Family Business: An Exploratory Study, Family Business Review, 20, 199-213.

Bohren, O. (2011). Eierne, styret og ledelsen, Corporate governance I Norge, Fagbokforlaget, Bergen. Booth, L., Aivazian, V., Demirguc-Kunt, A., and Maksimovic, V. (2001). Capital structures in developing countries, Journal of Finance, 39, 857-878.

Brealey, R. A., Myers, S. C., and Allen, F. (2006). Corporate Finance, McGraw-Hill Irwin.

Buferna, F., Bangassa, K., and Hodgkinson, L. (2005). Determinants of Capital Structure: Evidence from Libya, Research Paper Series, No. 2005/08. Management School, University of Liverpool.

Cekrezi, A. (2013). Analyzing the impact of firm's specific factors and macroeconomic factors on capital structure: A case of small non-listed firms in Albania, Research Journal of Finance and Accounting, 4(8), 90-95.

Chadha, S., and Sharma A. K. (2015). Determinants of capital structure: an empirical evaluation from India, Journal of Advances in Management Research, 12(1), 3-14.

Chen, J., and Strange, R. (2005). The determinants of capital structure: Evidence from Chinese listed companies, Economic Change and Restructuring, 38(1), 11-35.

Cheang, C. S. (2017). Corporate Governance Mechanisms and Performance of Public-Listed Surviving Family Firms In Malaysia, Unpublished Degree Dissertation, University Sains Malaysia, School of Management.

Chua, J. H., Chrisman, J. J., and Sharma, P. (1999). Defining the family business by behaviour, Entrepreneurship Theory and Practice, 23(4), 19-39.

Churchill, N. C., and Hattern, K. J. (1987). Non-Market-Based Transfer of Wealth and Power: A Research Framework for Small Business, Am. J. Small Bus, 11(3), 51-64.

Claessens, S., Djankov, S., and Lang, L. H. P. (2000). The Separation of Ownership and Control in East Asian Corporation, Journal of Financial Economics, 58, 81-112.

Cole, R. A. (2013). What do we know about the Capital Structure of Privately Held US Firms? Evidence from the Surveys of Small Business Finance, Journal of Financial Management, 42(4), 777-813.

Colot, O., and Croquet, M. (2009). Debt of family firms: a comparison based on accounting indicators, Corporate Ownership \& Control, 6(3), 53-60.

Craig, J. B., Dibrell, C., and Davis, P. S. (2008). Leveraging family-based brand identity to enhance firm competitiveness and performance in family business, Bond Business School Publications, 1-35.

Croci, E., Doukas, J. A., and Gonenc, H. (2011). Family Control and Financing Decisions, European Financial Management, 17(5), 860-897.

Daskalakis, N., and Psillaki, M. (2008). Do country of firm factors explain capital structure? Evidence from SMEs in France and Greece, Applied Financial Economics, 18, 87-97.

Deesomsak, R., Paudyal, K., and Pescetto, G. (2004). The determinants of the capital structure: Evidence from the Asia Pacific region, Journal of Multinational Financial Management, 14, 387-405.

Donaldson, G. (1961). Corporate Debt Capacity: A Study of Corporate Debt Policy and the Determination of Corporate Debt Capacity, Boston: Harvard University, Graduate School of Business Administration, Division of Research. 
INTERNATIONAL JOURNAL OF ACADEMIC RESEARCH IN ACCOUNTING, FINANCE AND

MANAGEMENT SCIENCES

Vol. 11, No. 2, 2021, E-ISSN: 2225-8329 @ 2021 HRMARS

Faccio, M., and Lang, L. H. P. (2002). The Ultimate Ownership of Western European Corporations, Journal of Financial Economics, 65, 365-395.

Fan, J. P. H., and Wong, T. J. (2002). Corporate ownership structure and the informativeness of accounting earnings in East Asia. Journal of Accounting and Economics, 33, 401-425.

Mouamer, F. M. A. (2011). The Determinants of Capital Structure of Palestine-listed Companies, Journal of Risk Finance, 12(3), 226-241.

Frank, M. Z., and Goyal, V. K. (2009). Capital structure decision: which factors are reliability important, Financial Management, 39(1), 1-37.

Friend, I., and Lang, L. H. P. (1988). An empirical test of the impact of managerial self-interest on corporate capital structure. Journal of Finance, 43, 217-281.

Gallo, M.A, Tapies J. and Cappuyns, K. (2004): Comparison of Family and Nonfamily Business: Financial Logic and Personal Preferences, Family Business Review, 17(4), 303-318.

Gomez-Mejia, L. R., Haynes, K. T., Nunez-Nickel, M., Jacobson, K. J. L., and Moyano-Fuentes, J. (2007). Socioemotional wealth and business risks in family-controlled firms: Evidence from Spanish olive oil mills, Administrative Science Quarterly, 52(1), 106-137.

Gorriz, C. G., and Fumas, V. S. (1996). Ownership Structure and Firm Performance: Some Empirical Evidence from Spain, Managerial and Decision Economics, 17, 575-586.

Gorriz, C. G., and Fumas, V. S. (2005). Family Ownership and Performance: The Net Effect of Productive Efficiency and Growth Constraints, Finance Working Paper N, 66/2005, University of Zaragoza.

Handler, W. C. (1989). Managing Succession in Family Firms: The Next Generation Family Member's Experience, Unpublished Doctoral Dissertation, Boston University School of Management.

Harris, M., and Raviv, A. (1990). Capital Structure and the Informational Role of Debt, The Journal of Finance, 45, 321-349.

Harris, M., and Raviv, A. (1991). The theory of capital structure, Journal of Finance, 46, 297-355.

Hussain, S. S., Hamza, S., and Miras, H. (2015). The Determinants of Capital Structure for Malaysian Food Producing Companies, International Journal of Accounting, Business and Management, 1(1), 2289-4519.

Ibrahim, H., and Samad, F. A. (2011). Corporate Governance Mechanisms and Performance of PublicListed Family-Ownership in Malaysia, International Journal Of Economics and Finance, 3(1).

Jamal, A. A. A., Mohidin, R., Sang, L. T., and Karamah, Z. A. B. U. (2011). Capital Structure Determinants: An Exploratory Study of Malaysian Companies in the Trading and Services Sector, Proceedings of the 5th Asian Academy of Applied Business (AAAB), Phnom Penh, Cambodia.

Jensen, M. C. (1986). Agency costs of free cash flow, corporate finance and takeovers, American Economic Review, 76, 323-329.

Jensen, M. C. (2000). A Theory of the Firm: Governance, Residual Claims, and Organizational Forms, Harvard University Press, Cambridge.

Jensen, M. C., and Meckling, W. H. (1976). Theory of the firm: Managerial behaviour, agency costs and ownership structure, Journal of Financial and Quantitative Analysis, 27, 247-263.

Johnson, S., Boone, P., Breach, A. and Friedman, E. (2000). Corporate governance in the Asian financial crisis. Journal of Financial Economics, 58, 141-186.

Kester, W. C. (1986). Capital and ownership structure: A comparison of United States and Japanese manufacturing corporations, Financial Management, 15, 5-16. 
INTERNATIONAL JOURNAL OF ACADEMIC RESEARCH IN ACCOUNTING, FINANCE AND

MANAGEMENT SCIENCES

Vol. 11, No. 2, 2021, E-ISSN: 2225-8329 ๑ 2021 HRMARS

La Rocca, M., La Rocca, T., and Cariola, A. (2011). Capital Structure Decisions during a Farms' Life Cycle, Small Business Economics, 37,107-130.

Lemmon, M. L., and Lins, K. V. (2001). Ownership structure, corporate governance and firm value: Evidence from the East Asian financial crisis. William Davidson Working Paper 393.

Lins, K. V. (2003). Equity ownership and firm value in emerging markets. Journal of Financial and Quantitative Analysis, 33(1), 159-184.

Long, M., and Malitz, I. (1985). The Investment-Financing Nexus: Some Empirical Evidence, Midland Corporate Finance Journal, 3, 53-59.

Lopez, G. J., and Sanchez, A. A. (2007). Financial structure of Family Business: Evidence from a Group of small Spanish Firms, Family Business Review, 269-287.

Mahmood, W. M. W., Affandi, S., Baharuddin, N. S., Mohamad, Z., and Shamsudin, N. (2011). Capital Structure of Property Companies in Malaysia, International Research Journal of Finance and Economics.

Mahmood, W. M. W., and Zakaria, R. (2007). Profitability and capital structure of the property and construction sectors in Malaysia, Pacific Rim Property Research Journal, 13(1), 92-105.

Mat Nor, F., and Yatim, C. P. (2000). Determinants of corporate debt ownership in Malaysia, Asian Academy of Management Journal, 5, 15-26.

Mat Kila, S., and Mahmood, W. M. W. (2008). Capital Structure and Firm Characteristics: Some Evidence from Malaysian Companies 23, MPRA Paper No. 14616, posted 13. April 2009 05:01 UTC.

Mazhar, A., and Nasr, M. (2010). Determinants of Capital Structure Decisions Case of Pakistani Government Owned and Private Firms, International Review of Business Research Papers, 6, 40-46.

Medeiros, C. (2015). Can family ownership influence firms' capital structure decision? Unpublished Master Dissertation, Catholic University of Portugal, School of Business \& Economics.

Megginson, W. L. (1997). Corporate finance theory, United Stated, Addison.

Miller, D., and Le-Breton-Miller, I. (2006). Family Governance and Firm Performance: Agency, Stewardship, and Capabilities, Family Business Review, 19, 73-787.

Mishra, C. S., and McConaughy, D. L. (1999). Founding Family Control and Capital Structure: The Risk of Loss of Control and the aversion to Debt, Entrepreneurship Theory and Practice, 23, 54-64.

Mishra, C. S., Randoy, T., and Jenssen, J. I. (2001). The Effect of Founding Family Influence on Firm Value and Corporate Governance, Journal of International Financial Management and Accounting, 12 (3), 235-259.

Modigliani, F., and Miller, M. H. (1958). The cost of capital, corporate finance and the theory of investment. American Economic Review, 48, 261-297.

Modigliani, F. ,and Miller, M. H. (1963). Corporate Income Taxes and the Cost of Capital: A Correction, The American Economic Review, 53(3), 433-443.

Molly, M., Laveren, E., and Deloof, M. (2010). Family Business Succession and its Impact on Financial Structure and Performance, Family Business Review, 23(2), 131-147.

Morck, R., Stangeland, D., and Yeung, B. (2000). A chapter in Concentrated Corporate Ownership, National Bureau of Economic Research, 319-372.

Myers, S. C. (1977). Determinants of corporate borrowing, Journal of Financial Economics, 5, 147175.

Myers, S. C. (1984). The capital structure puzzle, Journal of Finance, 39, 575-592. 
INTERNATIONAL JOURNAL OF ACADEMIC RESEARCH IN ACCOUNTING, FINANCE AND

MANAGEMENT SCIENCES

Vol. 11, No. 2, 2021, E-ISSN: 2225-8329 @ 2021 HRMARS

Myers, S. C. (1984). Capital structure, Journal of Economic Perspectives, 15, 81-102.

Myers, S. C., and Majluf, N. S. (1984). Corporate financing and investment decisions when firms have information investors do not have, Journal of Financial Economics, 13, 187-221.

Myers, S. C. (2001). Capital Structure, Journal of Economic Perspective, 15(2), 81-102.

Ohman, P., and Yazdanfar, D. (2017). Short- and long-term debt determinants in Swedish SMEs, Review of Accounting and Finance, 16(1), 106-124.

Pandey, I. M. (2001). Capital structure and the firm characteristics: Evidence from an emerging market, Indian Institute of Management Ahmedabad Working Paper No. 2001-10-04.

Pandey, I. M. (2004). Capital structure, profitability and market structure. Evidence from Malaysia, Asia Pacific Journal of Economics and Business, 8, 78-91.

Qian, Y., Yao, T., and Wirjanto, T. S. (2009). Do Chinese publicly listed companies adjust their capital structure toward a target level? China Economic Review, 20(4), 662-676.

Qiu, M., and La, B. (2010). Firm characteristics as determinants of capital structures in Australia, International Journal of the Economics of Business, 17(3), 277-287.

Rajan, R. G., and Zingales, L. (1995). What do we know about capital structure? Some evidence from international data, Journal of Finance, 50, 1421-1460.

Ramalho J., and Da Silva, J. V. (2009). A Two-part Fractional Regression Model for the Financial Leverage Decisions of Micro, Small, Medium and Large Firms, Quantitative Finance, 9(5), 621636.

Rao, N. S., and Lukose, J. (2002). An Empirical Study on the Determinants of the Capital Sructure of Listed Indian Firms, Working Paper. Powait: Shailesh J Mehta School of Management, Indian Institute of Technology Bombay.

Salwani, A., Mansor, W., Mahmood, W., and Samah, R. A. (2007). A Study on the Determinants of Capital Structure in Property Companies: Malaysian Evidence, Proceeding of the 1st Terengganu International Business and Economic Conference, Malaysia.

Scherr, F. C., and Hulburt, H. M. (2001). The Debt Maturity Structure of Small Firms, Financial Management, 30.

Sciascia, S., and Mazzola, P. (2008). Family involvement in ownership and management: Exploring nonlinear effects on performance, Family Business Review, 21(4), 331-345.

Seppa, R. (2008). Capital structure decisions: research in Estonian non-financial companies, Baltic Journal of Management, 3(1), 55-70.

Silva, F., and Majluf, N. (2008). Does family ownership shape performance outcomes? Journal of Business Research, 61(6), 609-614.

Sinha, S. (1992). Inter-Industry Variation in Capital Structure in India, Indian Journal of Finance and Research, 2, 13-26.

Song, H. S. (2005). Capital Structure Determinants - An Empirical Study of Swedish Companies, Working Paper The Royal Institute of Technology, Stockholm.

Sraer, D., and Thesmar, D. (2006). Performance and Behavior of Family Firms: Evidence from the French Stock Market, ECGI Working Paper No. 130/2006, http://ssrn.com/abstract_id=925415.

Stempler, G. (1988). The Study of Succession in Family Owned Businesses, Unpublished Doctoral Dissertation, George Washington University, Washington D.C.

Stiglitz, J. E. (1972). On the Optimality of the Stock Market Allocation of Investment, Quarterly Journal of Economics, 86. 
INTERNATIONAL JOURNAL OF ACADEMIC RESEARCH IN ACCOUNTING, FINANCE AND

MANAGEMENT SCIENCES

Vol. 11, No. 2, 2021, E-ISSN: 2225-8329 @ 2021 HRMARS

Titman, S., and Wessels, R. (1988). The determinants of capital structure choice. Journal of Finance, 43, 1-19.

Vergas, N., Cerqueira, A., and Brandao E. (2015). The Determinants of the Capital Structure of Listed on Stock Market Nonfinancial Firms: Evidence for Portugal, Working Paper, FEP-UP, School of Economics and Management, University of Porto, 555, 1-32.

Villalonga, B., and Amit, R. (2006). How do family ownership, control and management affect firm value? Journal of Financial Economics, 80, 385-417.

Wahlqvist, I., and Narula, S. (2014). The capital Structure, Ownership and Survival of Newly Established Family Firms, BI Norwegian Business School, Norwegian.

Wald, J. K. (1999). How firm characteristics affect capital structure: An international comparison. Journal of Financial Research, 22, 161-187.

Weller, C. (1998). Global Banking, Foreign Policy, 3(9), 1-3.

Wickramanayake, J. (2009). Capital structure of small and medium enterprise in Malaysia: An empirical investigation, Seminar Working Paper presented in Sunway Monash University, Malaysia in November 2009.

Williamson, O. E. (1988). Corporate Finance and Corporate Governance, Journal of Finance, 43 (3), 567-591.

Wiwattanakantang and Yupana. (1999). An empirical study on the determinants of the capital structure of Thai firms, Pacific-Basin Finance Journal, Elsevier, 7(3-4), 371-403.

Yammeesri, J., and Lodh, S. C. (2004). Is Family Ownership a Pain or Gain to Firm Performance? The Journal of American Academy of Business, Cambridge, 4(1/2), 263-270.

Yeh, Y. H., Lee, T. S., and Woidtke, T. (2001). Family Control and Corporate Governance: Evidence from Taiwan, International Review of Finance, 2(1/2), 21-48.

Zahra, S. A., and Sharma, P. (2004). Family Business Research: A Strategic Reflection, Family Business Review, 17(4), 331-346.

Zellweger, T. M., and Astrachan, J. H. (2008). On the emotional value of owning a firm, Family Business Review, 21(4), 347-363. 